\title{
ACERTO guidelines of perioperative nutritional interventions in elective general surgery
}

\section{Diretriz ACERTO de intervenções nutricionais no perioperatório em cirurgia geral eletiva}

José Eduardo de-Aguilar-Nascimento, TCBC-MT1,2; Alberto Bicudo Salomão, ACBC-MT1; Dan Linetzky Waitzberg, TCBC-SP3; Diana Borges Dock-Nascimento'; Maria Isabel T. D. Correa, TCBC-MG4; Antonio Carlos L. Campos, TCBC-PR5; Paulo Roberto Corsi, TCBC-SP6; Pedro Eder Portari Fllho, TCBC-RJ; Cervantes Caporossi, TCBC-MT; Comissão de Cuidados Perioperatórios do Colégio Brasileiro de Cirurgiöes. Sociedade Brasileira de Nutrição Parenteral e Enteral (SBNPE).

\section{A B S T R A C T}

\begin{abstract}
Objective: to present recommendations based on the ACERTO Project (Acceleration of Total Post-Operative Recovery) and supported by evidence related to perioperative nutritional care in General Surgery elective procedures. Methods: review of relevant literature from 2006 to 2016, based on a search conducted in the main databases, with the purpose of answering guiding questions previously formulated by specialists, within each theme of this guideline. We preferably used randomized controlled trials, systematic reviews and meta-analyzes but also selected some cohort studies. We contextualized each recommendation-guiding question to determine the quality of the evidence and the strength of this recommendation (GRADE). This material was sent to authors using an open online questionnaire. After receiving the answers, we formalized the consensus for each recommendation of this guideline. Results: the level of evidence and the degree of recommendation for each item is presented in text form, followed by a summary of the evidence found. Conclusion: this guideline reflects the recommendations of the group of specialists of the Brazilian College of Surgeons, the Brazilian Society of Parenteral and Enteral Nutrition and the ACERTO Project for nutritional interventions in the perioperative period of Elective General Surgery. The prescription of these recommendations can accelerate the postoperative recovery of patients submitted to elective general surgery, with decrease in morbidity, length of stay and rehospitalization, and consequently, of costs.
\end{abstract}

Keywords: Perioperative Care. Nutritional Therapy. Protocols. Practice Guideline.

\section{INTRODUCTION}

d n recent years there has been important technological developments in the fields of surgery and anesthesia. Many perioperative conducts, usually employed and empirically passed over decades, are now obsolete in the light of evidence and should therefore be abandoned. New equipment and new access techniques to body cavities have been developed thanks to laparoscopic and robotic operations. Laparoscopy alone showed that traditional care, such as early postoperative feeding and discharge are safe and feasible. In parallel, several guidelines of multimodal protocols $s^{3,4}$ based on randomized studies and meta-analyzes have also shown in recent years that even in large open operations it is possible to abbreviate preoperative fasting with liquids containing carbohydrates for two hours before anesthesia, to feed early in the postoperative period and to reduce the length of hospital stay safely.

In 2005, the ACERTO Project (Acceleration of Total Postoperative Recovery), based on a large bibliographical review on perioperative care, initiated a pioneering multimodal program in the Brazilian territory, which, from its conception, highlighted the importance of nutritional issues in the recovery of the surgical patient ${ }^{5}$. Evidence-based Medicine has widely shown that postoperative recovery-acceleration programs, similar to ACERTO, are safe, reduce postoperative com-

1 - Federal University of Mato Grosso, Post-Graduate Course in Health Sciences, Cuiabá, MT, Brazil. 2 - Várzea Grande University Center (UNIVAG), Várzea Grande, MT, Brazil. 3 - University of São Paulo, Faculty of Medicine, Department of Gastrenterology, São Paulo, SP, Brazil. 4 - Federal University of Minas Gerais, Alfa Institute of Gastrenterology, Clinics Hospital, Belo Horizonte, MG, Brazil. 5 - Federal University of Paraná, Post-Graduation Program in Clinical Surgery, Curitiba, PR, Brazil. 6 - Faculty of Medical Sciences of the Santa Casa de São Paulo, Department of Surgery, São Paulo, SP, Brazil. 7 - Federal University of the State of Rio de Janeiro (UNIRIO), Department of General and Specialized Surgery, Rio de Janeiro, RJ, Brazil. 
plications and hospitalization time, without increasing readmission rates ${ }^{6-8}$.

Although the association between malnutrition and adverse postoperative outcomes is well known, the prescribing of perioperative nutritional therapy as recommended by these modern guidelines, supported by important medical societies, is still forgotten among surgeons ${ }^{9}$. With more than ten years of existence, the ACERTO Project has been increasingly widespread and used throughout the country, as well as in Latin American countries that have epidemiological realities and similar conducts to those we have in Brazil. Being a model for dynamic decision-making, throughout this period the program has been constantly updated, including new scientific information from the publication of methodologically well-designed studies. The purpose of this Guideline is to present recommendations from specialists of the Brazilian College of Surgeons and the Brazilian Society of Parenteral and Enteral Nutrition on various nutritional prescriptions applied to the perioperative period of elective procedures in general surgery based on the latest evidence proposed by the ACERTO Multimodal Project.

\section{METHODS}

The authors searched the main databases (Medline, Scopus, SciELO and Cochrane) between 2006 and 2016 on clinical studies involving perioperative nutritional care for elective operations in general surgery following the precepts of McKeever et al. ${ }^{10}$. The Medical Subjects Headings used as keywords were "fasting", "preoperative care", "surgery", "nutritional therapy", "perioperative care" and "immune nutrition". The keywords were combined individually or together with other specific areas of general surgery such as "colon", "stomach", "esophagus", "pancreas", "gallbladder", "liver", "Biliary tract", etc. In addition, we also searched for terms not present in Medical Subjects Headings such as "fast track", "enhanced recovery after surgery", "ERAS", "ACERTO". Some routines and guidelines were cited in some contexts, but did not interfere in the evaluation of the recommendations. We excluded review articles (non-systematic) and consensuses. We selected randomized controlled trials, systematic reviews and meta-analyzes. In the absence of these studies, we also selected and analyzed cohort studies with appropriate methods.

We defined "General surgery" in the context of this Guideline as those procedures performed on the digestive tract, abdominal wall and head and neck surgery. Excluded from this definition were surgery for abdominal organ transplantation, those performed on an emergency basis or in critical care, pregnant and pediatric patients.

The authors first elaborated recommendations on several topics, previously selected and grouped as answers to guiding questions, formulated in order to address the main issues inherent to the decision-making process of the surgical patient, in the context of the objectives proposed for this Guideline. Each recommendation was then put to the vote and suggestions, by means of an anonymous questionnaire for collecting information, specially constructed for the elaboration of this Guideline, using the online SurveyMonkey® tool (http://www.surveymonkey.com, SurveyMonkey Inc., Palo Alto, Calif., USA), and based on the adapted Delphi method $^{11}$. A consensus was reached when at least $60 \%$ of the panel authors agreed with each recommendation.

The quality of the evidence and the strength of the recommendations were graded by the GRADE System (Grading of Recommendations, Assessment, Development and Evaluation) ${ }^{12}$. By this method, each information is assigned a degree of evidence and a strength of recommendation. The degree of evidence represents confidence in the information used and was classified into four levels: High, Moderate, Low or Very Low. In turn, the strength of recommendation expresses the emphasis on whether a particular conduct is adopted or rejected, considering potential advantages and disadvantages, such as effect size, quality of evidence and intervention costs, and was classified as Strong or Weak. To exemplify, a recommendation classified as Strong would be one in which the authors are confident that the desired effects on adherence to this recommendation outweigh possible undesirable effects. On the other hand, a Weak recommendation would be one in which the desired effects on adhe- 
rence to a particular conduct also outweighs undesirable effects, but the authors are not so confident for a Strong recommendation. It is necessary to clarify that the recommendation (Strong or Weak) is not only based on the quality of the studies that support it, but also on the balance between desirable and undesirable effects of the conduct applied In this way, a Strong recommendation, for example, may have a low quality of evidence.

\section{ve information?}

\section{Should the patient receive preoperati-}

"The patient should receive, preferably in writing (booklet, pamphlet) guidelines and advice that help him/her have a fast recovery in the perioperative period."

\section{Degree of recommendation: STRONG Evidence Strength: LOW}

Transmitting some information about the operation to the patient may decrease anxiety, as well as "help one help oneself" postoperatively ${ }^{13}$. For example, knowing that one can shorten preoperative fasting time for certain types of liquids, that one can feed and ambulate early postoperatively, etc., may increase the patient's adherence to these behaviors, especially at times when the surgeon or other members of the multiprofessional team are not present. Likewise, preoperative information enables preconceived or ingrained ideas about the perioperative period, such as the prohibition of walking or the need for an excessively long period of fasting, to be clarified and no longer affect or interfere with the conduct of accelerated recovery through the multimodal program.

This information should be preferably available in the form of a pamphlet or small booklet that should be given to the patient. Aguilar-Nascimento et al. ${ }^{15}$ observed a lower risk of nausea and postoperative pain in the group that received preoperative information in a systematized manner. The information should include, in addition to estimated discharge time, nutritional guidelines of abbreviated preoperative fasting (six hours for solids and two hours for carbohydrate containing liquids), early feedback and ambulation, among others.
2. Should a pre-habilitation program be recommended prior to surgery?

"A pre-habilitation program should be performed before surgery in patients at higher risk (less functional reserve) by combining physical exercises with other measures, such as adequate nutritional care. Most studies show improvement in postoperative functional capacity, but without reducing the rate of complications and without reducing length of hospital stay."

\section{Degree of Recommendation: WEAK Evidence Strength: LOW}

Malnutrition is an important cause for decreased muscle mass. However, currently other situations in which loss of muscle mass may have occurred have been well studied, among them sarcopenia. Primary sarcopenia is related to the aging process, but other causes have also been associated $^{16}$. Because sarcopenia is amenable to reversal through nutritional interventions and progressive resistance training, it becomes a potentially modifiable risk factor in elective surgical patients. In the postoperative period, several factors can alter body composition, especially at the expense of muscle mass consumption. The operation must be analyzed from the metabolic point of view as a planned trauma. The purpose of the surgical pre-habilitation is to prepare the patient to support the surgical stress with the least possible physical and functional repercussion, with the improvement of the parameters of physical conditioning before the operation, in order to optimize postoperative recovery and to maintain the muscular physical function. The ideal pre-habilitation program should be done for a period of four weeks, intercalating aerobic and resistance exercises ${ }^{17}$. In addition to nutritional care and physical conditioning, other care should be part of the preoperative optimization, such as cessation or reduction of smoking and alcohol use, optimization of doses of medications used, and compensating diabetes mellitus, hypertension and cardiopulmonary function whenever indicated.

Li et al. ${ }^{18}$ carried out a study in patients submitted to resection of colorectal cancer in two periods, 
before and after the intervention with pre-habilitation. The results showed benefits in functional capacity only in patients in the intervention group. There was no difference in morbimortality or hospitalization time. However, Valkenet et al. ${ }^{19}$, in a systematic review, showed that preoperative physical exercises are effective in decreasing the time of postoperative hospitalization and reducing complications in patients undergoing cardiac and abdominal surgery. In another study, 77 patients who were candidates for colorectal cancer surgery were randomized to receive preoperative exercises for four weeks at home $(n=38)$ or not $(n=39)$. Again, there was improvement in physical capacity tests, but there was no difference in terms of postoperative complication rates and hospitalization time ${ }^{20}$. Bruns et al. ${ }^{21}$ recently published a systematic review involving five studies in the elderly undergoing colorectal surgery. None of the studies showed improvement in complication rates and length of hospital stay. Four studies showed improvement in functional capacity with pre-habilitation.

\section{Is there a benefit in prescribing preo- perative nutritional therapy?}

"Oral, enteral or parenteral preoperative nutritional therapy should be instituted for patients who are candidates to moderate to major operations and have moderate to high nutritional risk, accessed by any of the available methods."

\section{Degree of recommendation: STRONG Evidence Strength: HIGH}

The nutritional status interferes with the postoperative results. The more compromised the nutritional status, the higher the risks of morbidity and mortality, and therefore the higher hospital costs ${ }^{22,23}$. This is much more evident among the elderly ${ }^{24}$. The preoperative evaluation of nutritional status and, even better, nutritional risk for postoperative morbidity and mortality should be established preferentially by the use of the NRS- $2002^{25}$ tool. In this context, the prescription of 5-10 days of preoperative nutritional therapy, preferably by the oral use of protein supplements or, if not possible, enterally or parenterally, improves the aforementioned outcomes ${ }^{26-30}$. The positive results of this nutritional intervention were demonstrated mainly in studies involving patients operated on for cancer of the digestive tract or of the head and neck region 31,32

\section{Are immunonutrient-containing for-} mulations indicated in the perioperative period?

"The nutritional formula used in the perioperative period may contain immunonutrients or not. However, in patients at greater risk and undergoing major surgery, nutritional therapy should include immunonutrients, both by the oral and enteral routes."

\section{Degree of recommendation: STRONG Evidence Strength: HIGH}

In recent years, much emphasis has been placed on the use of immunonutrition as a complement to the protein formula of oral supplements or enteral nutrition. Most of the studies used nutritional formulas containing arginine, omega- 3 fatty acids and nucleotides. This interaction of immunonutrients can favorably modulate the inflammatory response, improve the immune response and promote healing ${ }^{33}$. Although there are studies that have not shown differences in postoperative outcomes ${ }^{34}$, in the great majority of them the use of diet with immunonutrients was related to the reduction of complications, mainly infectious, and decreased hospitalization time ${ }^{35-37}$. The addition of arginine, omega-3 fatty acids and nucleotides to conventional nutritional supplements confer these additional perioperative nutritional advantages. There are more than 50 prospective, randomized studies on the subject in the literature today, which were the subject of five meta-analyzes. Braga et al. ${ }^{38}$ recently reviewed the five meta-analyzes and consistently confirmed that in severe or moderate malnutrition, pre-operative nutritional therapy for seven to 14 days with diets enriched with immunonutrients is associated with reduction of postoperative infections and length of hospital stay. In addition, these benefits may be associated with a reduction in hospital costs, considering the reduction of length of stay in the ICU, antibiotic use, length of mechanical ventilation time, risk of rehospitalization etc ${ }^{39}$. In head and neck surgery, a meta-analysis showed a decrease in length of hospital stay, though with no significant difference in 
the incidence of postoperative complications with the use of an immunomodulatory diet ${ }^{40}$. Regarding the most appropriate period of administration, a recent meta-analysis suggested that administering diets enriched with immunonutrients is more beneficial throughout the perioperative period (pre and postoperative) or only postoperatively than only preoperatively ${ }^{37}$.

\section{How should preoperative fasting be} prescribed to ensure patient safety and benefit?

"Pre-operative fasting should not be prolonged. For most patients who are candidates for elective procedures, it is recommended they fast six to eight hours before anesthetic induction. Carbohydrate-containing liquids (maltodextrin) should be ingested up until two hours of anesthesia, except for cases of delayed esophageal or gastric emptying or emergency procedures."

\section{Degree of recommendation: STRONG Evidence Strength: HIGH}

There is extensive documentation in the literature showing safety in the abbreviation of fasting for two hours prior to anesthetic induction ${ }^{41,42}$. The volume of gastric residue with 12 , eight, or six hours of complete fasting is similar to that found in fasting of six hours for solids and two hours for clear liquids, with or without carbohydrates ${ }^{43,44}$. The meta-analysis results involving 27 studies and 1976 participants did not show any case of aspiration or pneumonia with the abbreviation of preoperative fasting for $2 \mathrm{~h}$ to $3 \mathrm{~h}^{45}$. For this reason, a recent systematic review of 19 different preoperative fasting guidelines showed that there is agreement in recommending avoiding prolonged fasting and safety in the prescription of clear liquids containing or not carbohydrates up to two hours prior to anesthetic induction ${ }^{46}$. Although fasting after midnight is a difficult dogma to be modified, some studies show an increasing adherence of surgeons and anesthetists in adopting these new recommendations ${ }^{47}$.

Despite contradictory findings ${ }^{48}$, the benefits of the abbreviation of preoperative fasting, pointed out by several authors, are in the improvement of metabolic parameters, especially with the reduction of insulin resistance ${ }^{33,49-51}$, immunomodulation with less inflammatory reaction ${ }^{52-56}$ and increased postoperative functional capacity ${ }^{57}$. Studies also show a reduction in hospitalization time in larger operations ${ }^{58,59}$, reduction of anxiety, thirst and hunger ${ }^{32,33,60,61}$, and reduction of postoperative nausea and vomiting ${ }^{62,63}$.

\section{Can carbohydrate and protein-contai-} ning beverages be used to shorten preoperative fasting?

"Beverages containing carbohydrates associated with protein source (glutamine or whey protein) can safely be ingested up until three hours before the anesthetic procedure."

\section{Degree of Recommendation: WEAK Strength of Evidence: MODERATE}

The addition of nitrogen source containing glutamine, protein hydrolyzate or whey protein to the carbohydrate-containing beverage, besides being safe ${ }^{64,65}$, seems to increase the benefits associated with improved insulin sensitivity, functional capacity, higher glutathione production and lower acute Inflammatory reaction $42,43,66,67$. Although all randomized studies to date indicate safety, they are still few in comparison to those who used only maltodextrin and, in addition, they included few patients ${ }^{42,43,66,67}$.

Some old limitations of the abbreviation of preoperative fasting are being modified, such as for the diabetic patient or for the patient undergoing obesity surgery. There have been at least three randomized studies that have shown safety in abbreviating fasting in obese patients undergoing bariatric surgery ${ }^{68-70}$. Patients with controlled diabetes mellitus, not using without insulin and without gastroparesis can undergo abbreviated fasting ${ }^{71}$. However, due to the lack of studies in these groups of patients, it should be considered that more data are needed for a better understanding of the abbreviation of fasting in morbidly obese and diabetic patients.

7. When should feeding be restarted in the postoperative period?

"Oral or enteral feeding should restart earIy after elective abdominal surgery (within 24 hours) as long as the patient is hemodynamically stable. This 
recommendation applies even in cases of digestive anastomoses. In operations such as laparoscopic colecystectomy, herniorrhaphy and anorectal surgery, immediate onset of diet and oral hydration is recommended, without the use of intravenous hydration."

\section{Degree of recommendation: STRONG} Evidence Strength: HIGH

There is extensive documentation in the literature about the safety of early refeeding of patients submitted to elective abdominal, anorectal, or abdominal wall procedures. Meta-analyzes and randomized studies published over a decade ago report the safety of such conduct ${ }^{72-75}$. This includes upper digestive tract operations, such as esophagectomies ${ }^{76,77}$, gastrectomies $^{78}$ and duodenopancreatectomies ${ }^{79}$. In addition to safety in relation to the occurrence of anastomotic dehiscence, several of these authors demonstrated a decrease in infectious complications and length of hospitalization ${ }^{80-82}$. The oral route should be the first option for early feedback, even after large procedures $^{83}$. The current trend in the postoperative period is to avoid prolonged fasting and to abandon the classic oral diet from liquid to pasty and finally solid and to allow an oral precocious diet at will ${ }^{81,84}$.

According to the reviewed studies, although the tolerance of the patient to the resumption of the diet is not universal, it is generally high ${ }^{85-87}$ (above $70 \%)$, and may be even greater with the association of the prescription of other perioperative routines present in multimodal acceleration protocols of postoperative recovery. These include preoperative information (as discussed above), use of chewing gum from the immediate postoperative period on ${ }^{88}$, early mobilization ${ }^{89}$, use of prokinetic drugs such as alvimopan $^{90}$ (not yet marketed in Brazil), non-use of opioid medication ${ }^{91}$, and avoiding overload of perioperative intravenous fluids through the use of more rigorous therapy strategies (target-directed therapy) ${ }^{92,93}$ or even restrictive ones ${ }^{94}$, especially with regard to the use of crystalloid solutions and with high sodium content.

Still in this respect, careful management of intravenous crystalloid liquids on the day of operation is warranted. The greater the volume infused, the longer the postoperative ileus period, the greater the intolerance to the early diet and the longer the hospitalization ${ }^{90,95}$. Finally, the use of intravenous lidocaine for analgesia under continuous infusion has shown to accelerate recovery of postoperative ileus and increase tolerance to resumption of postoperative feeding ${ }^{96}$

\section{nal therapy be prescribed?}

I. "Postoperative nutritional therapy by catheter (naso-jejunal, naso-gastric, gastrostomy or jejunostomy), should be considered at an early stage (24 hours postoperatively): 1) for patients undergoing major operations of the head and neck (i.e, total laryngectomy) and upper gastrointestinal tract (esophageal resections, total gastrectomy, and pancreatic resections / shunts), when early oral nutrition is impossible or not recommended; or 2) in those patients who cannot reach $60 \%$ of the proposed nutritional goal after 5 to 7 days postoperatively with the oral route alone."

\section{Degree of recommendation: STRONG Evidence Strength: HIGH}

In some situations, usually associated with major operations, the oral route cannot be used or is not recommended. Patients with biliary and pancreatic cancer are a good example. Intolerance to the oral route due to previous malnutrition, malabsorption, prolonged gastric stasis and, mainly, anorexia represent barriers to oral post-operative nutrition ${ }^{97}$. In these situations, postoperative nutrition should be precocious and prescribed enterally or parenterally ${ }^{98,99}$. In this perspective, studies conducted in the 1990s have shown that, when compared, enteral nutrition is associated with a lower risk of morbidity and length of hospital stay in the postoperative period than parenteral nutrition ${ }^{100,101}$. More recent studies continue to reaffirm the superiority of enteral nutrition in relation to parenteral nutrition ${ }^{72,102-104}$, although there are publications that have not shown differences in results between these routes when compared ${ }^{95,96}$. This is probably due to modifications in parenteral nutrition formulation.

For enteral therapy, the use of nasoenteric catheters, percutaneous gastrostomy or jejunostomies are recommended ${ }^{95,105}$. According to a recent syste- 
matic review, there is no definition as to which route (including oral) is ideal following esophagectomy ${ }^{106}$. Severe complications involving the catheter are more common with jejunostomy ${ }^{107,108}$. However, a recent randomized study showed that nutrition by nasoenteric catheter or by jejunostomy is equivalent in terms of morbidity and length of stay, but jejunostomy allows the use of nutritional therapy for longer periods, especially in patients with complications, avoiding the use of parenteral nutrition ${ }^{109}$.

II. "Prescription of enteral formulas containing intact protein and low percentage of lipids is recommended in the majority of patients undergoing large abdominal operations. For severe malnourishment, cancer of the digestive system or cancer of the head and neck, nutritional therapy with immunonutrients is recommended."

\section{Degree of Recommendation: WEAK Strength of Evidence: MODERATE}

We identified no studies comparing formulas containing intact versus hydrolyzed protein in the postoperative period. Many studies, however, have been carried out with polymeric formulas. A recent randomized study compared the use of low-fat elemental formula with polymer formulation and with normal percentage of fat in patients submitted to esophagectomy and extended lymphadenectomy due to cancer. The elemental formula with low fat content was associated to a lower incidence of lymphatic fistula in the postoperative period ${ }^{110}$.

Formulas containing immunonutrients are indicated in the early postoperative period of malnourished patients in need of enteral nutrition. This recommendation is based on many randomized studies $^{111-113}$ and meta-analyzes ${ }^{102,104,114,115}$ that reported a lower rate of postoperative infection and length of hospital stay. However, there is no evidence of reduction in mortality.

It is recommended no more than $25 \mathrm{kcal} / \mathrm{kg} /$ day for most patients on enteral nutritional therapy in the first postoperative days, with protein intake of approximately $1.5 \mathrm{~g} / \mathrm{kg} /$ day.

III. "When it is impossible to use the digesti- ve tract or when the caloric supply fails to reach $60 \%$ of the planned caloric target after five postoperative days, parenteral nutritional therapy should be prescribed, either alone or in combination with enteral nutrition."

\section{Degree of Recommendation: WEAK Evidence Strength: LOW}

No randomized trials were conducted in postoperative patients whose objective was to compare clinical results with parenteral nutrition alone or in combination with enteral nutrition. Likewise, we identified no randomized trials comparing the best period for initiation of parenteral nutrition in the postoperative period. There are studies that have evaluated the timing of initiating parenteral nutrition in critically ill intensive care patients, but are beyond the scope of this guideline. The early initiation of parenteral nutrition (up to the third postoperative day) has been recommended in societies guidelines when isolated enteral nutrition is not sufficient or contraindicated ${ }^{116}$, as opposed to prolonged ileus, for example. Some guidelines for intensive care patients (involving several types of patients, including those in the postoperative period) recommend the associated or isolated use of parenteral nutrition only after the first postoperative week $^{117,118}$

Formulas containing omega-3 fatty acids determine a minor postoperative acute-phase inflammatory reaction 19-121, although this has not been confirmed in some studies. The use of intravenous glutamine in the postoperative period of patients receiving parenteral nutrition was safe in a recent multicenter study ${ }^{122}$. However, it did not modify the postoperative clinical results ${ }^{123}$.

\section{In what patients should specialized} nutritional therapy be maintained after discharge?

"Oral nutritional therapy (with oral supplements) or enteral nutrition should be maintained after discharge in patients who have used nutritional therapy in the perioperative period and still cannot maintain protein-calorie needs only by mouth."

Degree of recommendation: STRONG 


\section{Evidence Strength: LOW}

The risk of postoperative infectious complications in malnourished patients, especially in large operations, is quite high. In recent years, special attention has been devoted to the risk of rehospitalization in surgical patients ${ }^{124}$. In addition to being an indicator of morbidity, readmissions are strongly correlated with increased hospital costs ${ }^{125}$. The main risk factors associated with rehospitalization in this group are malnutrition and inadequate functional status (high ASA score, for example) ${ }^{126-128}$. As previously discussed, perioperative nutritional therapy is recommended in these cases, as there is sufficient evidence that this can positively influence this outcome and reduce the need for rehospitalization. However, many patients on perioperative nutritional therapy are discharged after a few days without guidance to maintain adequate nutrient supply. This leads to a greater risk of rehospitalization and of high late morbidity and mortality ${ }^{129}$.

The use of nutritional strategies, including the prescription of oral supplements in the postoperative period and after discharge from patients undergoing major operations, can prevent complications and reduce the chances of readmission ${ }^{130,131}$. This is especially important in elderly patients ${ }^{132}$. Maintenance of enteral nutrition in home care (with home-based nutritional therapy) may contribute to increase nutritional intake after major operations ${ }^{133}$ and prevent post-operative nutritional deterioration ${ }^{134,135}$.

\section{Areas for future research}

Few studies have investigated the effects of preoperative education on elective general elective surgery patients, although there is a strong recommendation for this practice. There is also a lack of studies on the effects of pre-habilitation on postoperative results. Further knowledge of the deleterious effects of preoperative sarcopenia and ways to reverse it before surgery can bring valuable information to improve recommendations in the future. Further studies on the use of nitrogen sources in preoperative oral supplements are also awaited, although there is enough literature to recommend them. Likewise, more studies on early feeding after esophagectomies and total gastrectomy are expected so as to enable the elaboration of specific recommendations on early oral route feeding for these operations.

There is also a lack of studies on formulas with intact or hydrolyzed nutrients in the postoperative period. In the same way, there is a lack of studies to clarify the best time to initiate parenteral nutrition therapy in non-critical patients postoperatively. In this article, we synthesized the possible recommendations in light of the evidence. The prescription of these recommendations can accelerate the postoperative recovery of patients submitted to elective general surgery, with decrease in morbidity, length of stay and rehospitalization, and consequently, of costs.

\section{REFERENCES}

\title{
RE S U M O
}

\begin{abstract}
Objetivo: apresentar recomendações, baseadas no Projeto ACERTO (Aceleração da Recuperação Total Pós-Operatória) e sustentada por evidências, relativas aos cuidados nutricionais perioperatórios em procedimentos eletivos em Cirurgia Geral. Métodos: revisão da literatura pertinente entre 2006 e 2016, com base em busca realizada nas principais bases de dados, com o intuito de responder a perguntas norteadoras previamente formuladas por especialistas, dentro de cada temática desta diretriz. Foram selecionados alguns estudos de coorte, mas, preferencialmente, foram utilizados estudos aleatórios controlados, revisões sistemáticas e meta-análises. Cada pergunta norteadora de recomendação foi contextualizada de modo a determinar a qualidade da evidência e a força desta recomendação (GRA$D E)$. Este material foi enviado aos autores utilizando um questionário aberto on-line. Após o recebimento das respostas, formalizou-se o consenso para cada recomendação desta diretriz. Resultados: o nível de evidência e o grau de recomendação para cada item é apresentado em forma de texto, seguido de resumo da evidência encontrada. Conclusão: esta diretriz traduz as recomendações do grupo de especialistas do Colégio Brasileiro de Cirurgiões, da Sociedade Brasileira de Nutrição Parenteral e Enteral e do Projeto ACERTO para intervenções nutricionais no período perioperatório em Cirurgia Geral eletiva. A prescrição dessas recomendações pode acelerar a recuperação pós-operatória de pacientes submetidos a operações eletivas em cirurgia geral, com diminuição de morbidade, do tempo de internação e de reinternações e, consequentemente, dos custos.
\end{abstract}

Descritores: Assistência Perioperatória. Terapia Nutricional. Protocolos. Guia de Prática Clínica. 
1. Correia MIT, Silva RG. Paradigmas e evidências da nutrição peri-operatória. Rev Col Bras Cir. 2005;32(6):342-7.

2. Steenhagen E. Enhanced Recovery After Surgery: it's time to change practice! Nutr Clin Pract. 2016;31(1):18-29.

3. Kehlet $\mathrm{H}$, Wilmore DW. Multimodal strategies to improve surgical outcome. Am J Surg. 2002;183(6):630-41.

4. Nygren J, Thacker J, Carli F, Fearon KC, Norderval $S$, Lobo DN, Ljungqvist $\mathrm{O}$, Soop $\mathrm{M}$, Ramirez J; Enhanced Recovery After Surgery Society. Guidelines for perioperative care in elective rectal/pelvic surgery: Enhanced Recovery After Surgery (ERAS $®)$ Society recommendations. Clin Nutr. 2012;31(6):801-16.

5. Aguilar-Nascimento JE, Bicudo-Salomão A, Caporossi C, Silva RM, Cardoso EA, Santos TP. Acerto pósoperatório: avaliação dos resultados da implantação de um protocolo multidisciplinar de cuidados perioperatórios em cirurgia geral. Rev Col Bras Cir. 2006;33(3):181-8.

6. Paton F, Chambers D, Wilson P, Eastwood A, Craig $D$, Fox $D$, et al. Initiatives to reduce length of stay in acute hospital settings: a rapid synthesis of evidence relating to enhanced recovery programmes. Southampton (UK): NIHR Journals Library; 2014.

7. Spanjersberg WR, Reurings J, Keus F, van Laarhoven CJ. Fast track surgery versus conventional recovery strategies for colorectal surgery. Cochrane Database Syst Rev. 2011;(2):CD007635.

8. Beamish AJ, Chan DS, Blake PA, Karran A, Lewis WG. Systematic review and meta-analysis of enhanced recovery programmes in gastric cancer surgery. Int J Surg. 2015;19:46-54.

9. Grass F, Cerantola Y, Schäfer M, Müller S, Demartines $N$, Hübner M. Perioperative nutrition is still a surgical orphan: results of a Swiss-Austrian survey. Eur J Clin Nutr. 2011;65(5):642-7.

10. McKeever L, Nguyen V, Peterson SJ, Gomez-Perez $S$, Braunschweig $C$. Demystifying the search button: a comprehensive PubMed search strategy for performing an exhaustive literature review. JPEN J Parenter Enteral Nutr. 2015;39(6):622-35.

11. Verhagen AP, de Vet HC, de Bie RA, Kessels AG, Boers
M, Bouter LM, et al. The Delphi list: a criteria list for quality assessment of randomized clinical trials for conducting systematic reviews developed by Delphi consensus. J Clin Epidemiol. 1998;51(12):1235-41.

12. Guyatt $G H$, Oxman AD, Vist GE, Kunz R, FalckYtter $Y$, Alonso-Coello $P$, Schünemann HJ; GRADE Working Group. GRADE: an emerging consensus on rating quality of evidence and strength of recommendations. BMJ. 2008;336(7650):924-6.

13. Kiecolt-Glaser JK, Page GG, Marucha PT, MacCallum RC, Glaser R. Psychological influences on surgical recovery. Perspectives from psychoneuroimmunology. Am Psychol. 1998;53(11):1209-18.

14. Short V, Atkinson C, Ness AR, Thomas S, Burden $S$, Sutton E. Patient experiences of perioperative nutrition within an Enhanced Recovery After Surgery programme for colorectal surgery: a qualitative study. Colorectal Dis. 2016;18(2):074-80.

15. de Aguilar-Nascimento JE, Leal FS, Dantas DC, Anabuki NT, de Souza AM, Silva E Lima VP, et al. Preoperative education in cholecystectomy in the context of a multimodal protocol of perioperative care: a randomized, controlled trial. World J Surg. 2014;38(2):357-62.

16. Cruz-Jentoft AJ, Baeyens JP, Bauer JM, Boirie $Y$, Cederholm T, Landi F, Martin FC, Michel JP, Rolland Y, Schneider SM, Topinková E, Vandewoude M, Zamboni M; European Working Group on Sarcopenia in Older People. Sarcopenia: European consensus on definition and diagnosis: report of the European Working Group on Sarcopenia in Older People. Age Ageing. 2010; 39(4):412-23.

17. Gonzalez MC. Composição corporal em cirurgia e pré-habilitação. In: Aguilar-Nascimento JE, BicudoSalomão A, Caporossi C, editores. ACERTO: acelerando a recuperação total pós-operatória. 3a ed. Rio de Janeiro: Rubio; 2016. p. 81.

18. Li C, Carli F, Lee L, Charlebois P, Stein B, Liberman AS, et al. Impact of a trimodal prehabilitation program on functional recovery after colorectal cancer surgery: a pilot study. Surg Endosc. 2013;27(4):1072-82.

19. Valkenet K, van de Port IG, Dronkers JJ, de Vries WR, Lindeman E, Backx FJ. The effects of preoperative exercise therapy on postoperative outcome: a systematic review. Clin Rehabil. 2011;25(2):99-111. 
20. Gillis C, Li C, Lee L, Awasthi R, Augustin B, Gamsa $A$, et al. Prehabilitation versus rehabilitation: a randomized control trial in patients undergoing colorectal resection for cancer. Anesthesiology. 2014;121(5):937-47.

21. Bruns ER, van den Heuvel B, Buskens CJ, van Duijvendijk P, Festen S, Wassenaar EB, et al. The effects of physical prehabilitation in elderly patients undergoing colorectal surgery: a systematic review. Colorectal Dis. 2016;18(8):0267-77.

22. Mosquera C, Koutlas NJ, Edwards KC, Strickland A, Vohra NA, Zervos EE, et al. Impact of malnutrition on gastrointestinal surgical patients. J Surg Res. 2016;205(1):95-101.

23. Garth AK, Newsome CM, Simmance N, Crowe TC. Nutritional status, nutrition practices and post-operative complications in patients with gastrointestinal cancer. J Hum Nutr Diet. 2010;23(4):393-401.

24. van Stijn MF, Korkic-Halilovic I, Bakker MS, van der Ploeg T, van Leeuwen PA, Houdijk AP. Preoperative nutrition status and postoperative outcome in elderly general surgery patients: a systematic review. JPEN J Parenter Enteral Nutr. 2013;37(1):37-43.

25. Sun $Z$, Kong $X J$, Jing $X$, Deng RJ, Tian ZB. Nutritional Risk Screening 2002 as a predictor of postoperative outcomes in patients undergoing abdominal surgery: a systematic review and metaanalysis of prospective cohort studies. PLoS One. 2015;10(7):e0132857.

26. Kabata P, Jastrzębski T, Kąkol M, Król K, Bobowicz M, Kosowska A, et al. Preoperative nutritional support in cancer patients with no clinical signs of malnutrition--prospective randomized controlled trial. Support Care Cancer. 2015;23(2):365-70.

27. Burden S, Todd C, Hill J, Lal S. Pre-operative nutrition support in patients undergoing gastrointestinal surgery. Cochrane Database Syst Rev. 2012;11:CD008879.

28. Wu MH, Lin MT, Chen WJ. Effect of perioperative parenteral nutritional support for gastric cancer patients undergoing gastrectomy. Hepatogastroenterology. 2008;55(82-83):799-802.

29. Jie B, Jiang ZM, Nolan MT, Zhu SN, Yu K, Kondrup J. Impact of preoperative nutritional support on clinical outcome in abdominal surgical patients at nutritional risk. Nutrition. 2012;28(10):1022-7.

30. Gómez Sánchez MB, García Talavera Espín NV, Monedero Saiz T, Sánchez Álvarez C, Zomeño Ros Al, Nicolás Hernández $\mathrm{M}$, et al. [Evaluation of perioperative nutritional therapy in patients with gastrointestinal tract neoplasms]. Nutr Hosp. 2011;26(5):1073-80. Spanish.

31. Bozzetti F, Gianotti L, Braga M, Di Carlo V, Mariani L. Postoperative complications in gastrointestinal cancer patients: the joint role of the nutritional status and the nutritional support. Clin Nutr. 2007;26(6):698709.

32. Goonetilleke KS, Siriwardena AK. Systematic review of peri-operative nutritional supplementation in patients undergoing pancreaticoduodenectomy. JOP. 2006;7(1):5-13.

33. Hamza N, Darwish A, O'Reilly DA, Denton J, Sheen AJ, Chang $D$, et al. Perioperative enteral immunonutrition modulates systemic and mucosal immunity and the inflammatory response in patients with periampullary cancer scheduled for pancreaticoduodenectomy: a randomized clinical trial. Pancreas. 2015;44(1):41-52.

34. Klek S, Kulig J, Sierzega M, Szybinski P, Szczepanek $\mathrm{K}$, Kubisz $\mathrm{A}$, et al. The impact of immunostimulating nutrition on infectious complications after upper gastrointestinal surgery: a prospective, randomized, clinical trial. Ann Surg. 2008;248(2):212-20.

35. Zhang Y, Gu Y, Guo T, Li Y, Cai H. Perioperative immunonutrition for gastrointestinal cancer: a systematic review of randomized controlled trials. Surg Oncol. 2012;21(2):e87-95.

36. Rowan NR, Johnson JT, Fratangelo CE, Smith BK, Kemerer PA, Ferris RL. Utility of a perioperative nutritional intervention on postoperative outcomes in high-risk head \& neck cancer patients. Oral Oncol. 2016;54:42-6.

37. Osland E, Hossain MB, Khan S, Memon MA. Effect of timing of pharmaconutrition (immunonutrition) administration on outcomes of elective surgery for gastrointestinal malignancies: a systematic review and meta-analysis. JPEN J Parenter Enteral Nutr. 2014;38(1):53-69.

38. Braga M, Wischmeyer P, Drover J, Heyland D. Clinical 
evidence for pharmaconutrition in major elective surgery. J Parent Enteral Nutr. 2013;37(5 Suppl 1):66S-72S

39. Chevrou-Séverac $H$, Pinget $C$, Cerantola $Y$, Demartines N, Wasserfallen JB, Schäfer M. Costeffectiveness analysis of immune-modulating nutritional support for gastrointestinal cancer patients. Clin Nutr. 2014;33(4):649-54.

40. Stableforth WD, Thomas S, Lewis SJ. A systematic review of the role of immunonutrition in patients undergoing surgery for head and neck cancer. Int J Oral Maxillofac Surg. 2009;38(2):103-10.

41. Bilku DK, Dennison AR, Hall TC, Metcalfe MS, Garcea G. Role of preoperative carbohydrate loading: a systematic review. Ann R Coll Surg Engl. 2014;96(1):15-22.

42. Li L, Wang Z, Ying $X$, Tian J, Sun $T$, Yi K, et al. Preoperative carbohydrate loading for elective surgery: a systematic review and meta-analysis. Surg Today. 2012;42(7):613-24. Erratum in: Surg Today. 2012;42(11):1142.

43. Itou K, Fukuyama T, Sasabuchi Y, Yasuda H, Suzuki $N$, Hinenoya $H$, et al. Safety and efficacy of oral rehydration therapy until $2 \mathrm{~h}$ before surgery: a multicenter randomized controlled trial. J Anesth. 2012;26(1):20-7.

44. Yagci G, Can MF, Ozturk E, Dag B, Ozgurtas T, Cosar A, et al. Effects of preoperative carbohydrate loading on glucose metabolism and gastric contents in patients undergoing moderate surgery: a randomized, controlled trial. Nutrition. 2008;24(3):212-6.

45. Smith MD, McCall J, Plank L, Herbison GP, Soop M, Nygren J. Preoperative carbohydrate treatment for enhancing recovery after elective surgery. Cochrane Database Syst Rev. 2014;(8):CD009161.

46. Lambert E, Carey S. Practice Guideline Recommendations on Perioperative Fasting: a systematic review. JPEN J Parenter Enteral Nutr. 2016;40(8):1158-65.

47. Giuliani S, McArthur A, Greenwood J. Preoperative fasting among burns patients in an acute care setting: a best practice implementation project. JBI Database System Rev Implement Rep. 2015;13(11):235-53.

48. Mathur S, Plank LD, McCall JL, Shapkov P, Mcllroy $K$, Gillanders LK, et al. Randomized controlled trial of preoperative oral carbohydrate treatment in major abdominal surgery. Br J Surg. 2010;97(4):485-94.

49. Tamura $T$, Yatabe $T$, Kitagawa $H$, Yamashita $K$, Hanazaki K, Yokoyama M. Oral carbohydrate loading with $18 \%$ carbohydrate beverage alleviates insulin resistance. Asia Pac J Clin Nutr. 2013;22(1):48-53.

50. Dock-Nascimento DB, Aguilar-Nascimento JE, Linetzky Waitzberg D. Ingestion of glutamine and maltodextrin two hours preoperatively improves insulin sensitivity after surgery: a randomized, double blind, controlled trial. Rev Col Bras Cir. 2012;39(6):449-55

51. Faria MS, de Aguilar-Nascimento JE, Pimenta OS, Alvarenga LC Jr, Dock- Nascimento DB, Slhessarenko $\mathrm{N}$. Preoperative fasting of 2 hours minimizes insulin resistance and organic response to trauma after video-cholecystectomy: a randomized, controlled, clinical trial. World J Surg. 2009;33(6):1158-64.

52. Pinto Ados S, Grigoletti SS, Marcadenti A. Fasting abbreviation among patients submitted to oncologic surgery: systematic review. Arq Bras Cir Dig. 2015;28(1):70-3.

53. Zelić M, Štimac D, Mendrila D, Tokmadžić VS, Fišić $\mathrm{E}$, Uravić $\mathrm{M}$, et al. Preoperative oral feeding reduces stress response after laparoscopic cholecystectomy. Hepatogastroenterology. 2013;60(127):1602-6.

54. Dock-Nascimento DB, de Aguilar-Nascimento JE, Magalhaes Faria MS, Caporossi C, Slhessarenko $\mathrm{N}$, Waitzberg DL. Evaluation of the effects of a preoperative 2-hour fast with maltodextrine and glutamine on insulin resistance, acute-phase response, nitrogen balance, and serum glutathione after laparoscopic cholecystectomy: a controlled randomized trial. JPEN J Parenter Enteral Nutr. 2012;36(1):43-52.

55. Pexe-Machado PA, de Oliveira BD, Dock-Nascimento DB, de Aguilar- Nascimento JE. Shrinking preoperative fast time with maltodextrin and protein hydrolysate in gastrointestinal resections due to cancer. Nutrition. 2013;29(7-8):1054-9.

56. Melis GC, van Leeuwen PA, von Blomberg-van der Flier BM, Goedhart- Hiddinga AC, Uitdehaag BM, Strack van Schijndel RJ, et al. A carbohydrate-rich beverage prior to surgery prevents surgery-induced immunodepression: a randomized, controlled, clinical 
trial. JPEN J Parenter Enteral Nutr. 2006;30(1):21-6.

57. Zani FV, Aguilar-Nascimento JE, Nascimento DB, Silva AM, Caporossi FS, Caporossi C. Benefits of maltodextrin intake 2 hours before cholecystectomy by laparotomy in respiratory function and functional capacity: a prospective randomized clinical trial. Einstein (Sao Paulo). 2015;13(2):249-54.

58. Noblett SE, Watson DS, Huong H, Davison B, Hainsworth PJ, Horgan AF. Pre-operative oral carbohydrate loading in colorectal surgery: a randomized controlled trial. Colorectal Dis. 2006;8(7):563-9.

59. Awad S, Varadhan KK, Ljungqvist O, Lobo DN. A meta-analysis of randomised controlled trials on preoperative oral carbohydrate treatment in elective surgery. Clin Nutr. 2013;32(1):34-44.

60. Yildiz H, Gunal SE, Yilmaz G, Yucel S. Oral carbohydrate supplementation reduces preoperative discomfort in laparoscopic cholecystectomy. J Invest Surg. 2013;26(2):89-95.

61. Bopp C, Hofer S, Klein A, Weigand MA, Martin E, Gust R. A liberal preoperative fasting regimen improves patient comfort and satisfaction with anesthesia care in day-stay minor surgery. Minerva Anestesiol. 2011;77(7):680-6.

62. Hausel J, Nygren J, Thorell A, Lagerkranser $M$, Ljungqvist $O$. Randomized clinical trial of the effects of oral preoperative carbohydrates on postoperativenausea and vomiting after laparoscopic cholecystectomy. Br J Surg. 2005;92(4):415-21.

63. Singh BN, Dahiya D, Bagaria D, Saini V, Kaman L, Kaje $V$, et al. Effects of preoperative carbohydrates drinks on immediate postoperative outcome after day care laparoscopic cholecystectomy. Surg Endosc. 2015;29(11):3267-72.

64. Lobo DN, Hendry PO, Rodrigues G, Marciani L, Totman JJ, Wright JW, et al. Gastric emptying of three liquid oral preoperative metabolic preconditioning regimens measured by magnetic resonance imaging in healthy adult volunteers: a randomised doubleblind, crossover study. Clin Nutr. 2009;28(6):636-41.

65. Borges Dock-Nascimento D, Aguilar-Nascimento JE, Caporossi C, Sepulveda Magalhães Faria M, Bragagnolo R, Caporossi FS, et al. Safety of oral glutamine in the abbreviation of preoperative fasting: a double-blind, controlled, randomized clinical trial. Nutr Hosp. 2011;26(1):86-90.

66. Perrone F, da-Silva-Filho AC, Adôrno IF, Anabuki NT, Leal FS, Colombo T, et al. Effects of preoperative feeding with a whey protein plus carbohydrate drink on the acute phase response and insulin resistance. A randomized trial. Nutr J. 2011;10:66.

67. Henriksen MG, Hessov I, Dela F, Hansen HV, Haraldsted V, Rodt SA. Effects of preoperative oral carbohydrates and peptides on postoperative endocrine response, mobilization, nutrition and muscle function in abdominal surgery. Acta Anaesthesiol Scand. 2003;47(2):191-9.

68. Karlsson A, Wendel K, Polits S, Gislason H, Hedenbro $\mathrm{JL}$. Preoperative nutrition and postoperative discomfort in an ERAS setting: a randomized study in gastric bypass surgery. Obes Surg. 2016;26(4):7438.

69. Lemanu DP, Singh PP, Berridge K, Burr M, Birch C, Babor $R$, et al. Randomized clinical trial of enhanced recovery versus standard care after laparoscopic sleeve gastrectomy. Br J Surg. 2013;100(4):482-9.

70. Pimenta GP, Capellan DA, de Aguilar-Nascimento JE. Sleeve gastrectomy with or without a multimodal perioperative care. A randomized pilot study. Obes Surg. 2015;25(9):1639-46.

71. Dhatariya K, Levy N, Kilvert A, Watson B, Cousins $D$, Flanagan D, Hilton L, Jairam C, Leyden K, Lipp A, Lobo D, Sinclair-Hammersley M, Rayman G; Joint British Diabetes Societies. NHS Diabetes guideline for the perioperative management of the adult patient with diabetes. Diabet Med. 2012;29(4):420-33.

72. Zhuang CL, Ye XZ, Zhang CJ, Dong QT, Chen BC, Yu $Z$. Early versus traditional postoperative oral feeding in patients undergoing elective colorectal surgery: a meta-analysis of randomized clinical trials. Dig Surg. 2013;30(3):225- 32

73. Weng HQ, He XL, Li FX, Liu T, Wang PZ. [Enteral versus parenteral nutrition after gastrointestinal surgery: a meta-analysis of randomized controlled trials]. Zhonghua Wai Ke Za Zhi. 2009;47(18):136873. Chinese.

74. Osland E, Yunus RM, Khan S, Memon MA. Early versus traditional postoperative feeding in patients undergoing resectional gastrointestinal surgery: 
a meta-analysis. JPEN J Parenter Enteral Nutr. 2011;35(4):473-87.

75. Lewis SJ, Andersen HK, Thomas S. Early enteral nutrition within $24 \mathrm{~h}$ of intestinal surgery versus later commencement of feeding: a systematic review and meta-analysis. J Gastrointest Surg. 2009;13(3):56975.

76. Sun H, Li Y, Liu X, Wang Z, Zhang R, Qin J, et al. [Feasibility of "no tube no fasting" therapy in thoracolaparoscopic oesophagectomy for patients with oesophageal cancer]. Zhonghua Wei Chang Wai Ke Za Zhi. 2014;17(9):898-901. Chinese.

77. Mahmoodzadeh H, Shoar S, Sirati F, Khorgami Z. Early initiation of oral feeding following upper gastrointestinal tumor surgery: a randomized controlled trial. Surg Today. 2015;45(2):203-8.

78. Liu X, Wang D, Zheng L, Mou T, Liu H, Li G. Is early oral feeding after gastric cancer surgery feasible? A systematic review and meta-analysis of randomized controlled trials. PLoS One. 2014;9(11):e112062.

79. Park JS, Chung HK, Hwang HK, Kim JK, Yoon DS. Postoperative nutritional effects of early enteral feeding compared with total parental nutrition in pancreaticoduodectomy patients: a prosepective, randomized study. J Korean Med Sci. 2012;27(3):2617.

80. da Fonseca LM, Profeta da Luz MM, Lacerda-Filho A, Correia MI, Gomes da Silva R. A simplified rehabilitation program for patients undergoing elective colonic surgery--randomized controlled clinical trial. Int J Colorectal Dis. 2011;26(5):609-16.

81. Feo CV, Lanzara S, Sortini D, Ragazzi R, De Pinto M, Pansini GC, et al. Fast track postoperative management after elective colorectal surgery: a controlled trail. Am Surg. 2009;75(12):1247-51.

82. Han-Geurts IJ, Hop WC, Kok NF, Lim A, Brouwer KJ, Jeekel J. Randomized clinical trial of the impact of early enteral feeding on postoperative ileus and recovery. Br J Surg. 2007;94(5):555-61.

83. Gerritsen A, Besselink MG, Gouma DJ, Steenhagen E, Borel Rinkes IH, Molenaar IQ. Systematic review of five feeding routes after pancreatoduodenectomy. Br J Surg. 2013;100(5):589-98.

84. Lassen K, Kjaeve J, Fetveit T, Tranø G, Sigurdsson HK, Horn A, et al. Allowing normal food at will after major upper gastrointestinal surgery does not increase morbidity: a randomized multicenter trial. Ann Surg. 2008;247(5):721-9.

85. Kim HO, Lee SR, Choi WJ, Kim H. Early oral feeding following laparoscopic colorectal cancer surgery. ANZ J Surg. 2014;84(7-8):539-44.

86. Dag A, Colak T, Turkmenoglu O, Gundogdu R, Aydin S. A randomized controlled trial evaluating early versus traditional oral feeding after colorectal surgery. Clinics (Sao Paulo). 2011;66(12):2001-5.

87. Gianotti L, Nespoli L, Torselli L, Panelli M, Nespoli A. Safety, feasibility, and tolerance of early oral feeding after colorectal resection outside an enhanced recovery after surgery (ERAS) program. Int J Colorectal Dis. 2011;26(6):747-53.

88. Parnaby CN, MacDonald AJ, Jenkins JT. Sham feed or sham? A meta- analysis of randomized clinical trials assessing the effect of gum chewing on gut function after elective colorectal surgery. Int J Colorectal Dis. 2009;24(5):585-92.

89. Lee TG, Kang SB, Kim DW, Hong S, Heo SC, Park KJ. Comparison of early mobilization and diet rehabilitation program with conventional care after laparoscopic colon surgery: a prospective randomized controlled trial. Dis Colon Rectum. 2011;54(1):21-8.

90. Ludwig K, Enker WE, Delaney CP, Wolff BG, Du W, Fort JG, et al. Gastrointestinal tract recovery in patients undergoing bowel resection: results of a randomized trial of alvimopan and placebo with a standardized accelerated postoperative care pathway. Arch Surg. 2008;143(11):1098-105.

91. Kuzma J. Randomized clinical trial to compare the length of hospital stay and morbidity for early feeding with opioid-sparing analgesia versus traditional care after open appendectomy. Clin Nutr. 2008;27(5):694-9.

92. Gómez-Izquierdo JC, Feldman LS, Carli F, Baldini G. Meta-analysis of the effect of goal-directed therapy on bowel function after abdominal surgery. $\mathrm{Br} J$ Surg. 2015;102(6):577-89.

93. Rollins KE, Lobo DN. Intraoperative goal-directed fluid therapy in elective major abdominal surgery: a meta-analysis of randomized controlled trials. Ann Surg. 2016;263(3):465-76.

94. Khoo CK, Vickery CJ, Forsyth N, Vinall NS, Eyre- 
Brook IA. A prospective randomized controlled trial of multimodal perioperative management protocol in patients undergoing elective colorectal resection for cancer. Ann Surg. 2007;245(6):867-72.

95. Thacker JK, Mountford WK, Ernst FR, Krukas MR, Mythen MM. Perioperative fluid utilization variability and association with outcomes: considerations for enhanced recovery efforts in sample US surgical populations. Ann Surg. 2016;263(3):502-10.

96. Kranke P, Jokinen J, Pace NL, Schnabel A, Hollmann MW, Hahnenkamp K, et al. Continuous intravenous perioperative lidocaine infusion for postoperative pain and recovery. Cochrane Database Syst Rev. 2015;(7):CD009642.

97. Liu Y, Xue X. Systematic review of peri-operative nutritional support for patients undergoing hepatobiliary surgery. Hepatobiliary Surg Nutr. 2015;4(5):304-12.

98. Seike J, Tangoku A, Yuasa Y, Okitsu H, Kawakami $Y$, Sumitomo M. The effect of nutritional support on the immune function in the acute postoperative period after esophageal cancer surgery: total parenteral nutrition versus enteral nutrition. J Med Invest. 2011;58(1-2):75-80.

99. Kim HU, Chung JB, Kim CB. [The comparison between early enteral nutrition and total parenteral nutrition after total gastrectomy in patients with gastric cancer: the randomized prospective study]. Korean J Gastroenterol. 2012;59(6):407-13. Korean.

100. Reynolds JV, Kanwar S, Welsh FK, Windsor AC, Murchan P, Barclay GR, et al. 1997 Harry M. Vars Research Award. Does the route of feeding modify gut barrier function and clinical outcome in patients after major upper gastrointestinal surgery? JPEN J Parenter Enteral Nutr. 1997;21(4):196- 201.

101. Moore FA, Feliciano DV, Andrassy RJ, McArdle AH, Booth FV, Morgenstein- Wagner TB, et al. Early enteral feeding, compared with parenteral, reduces postoperative septic complications. The results of a meta-analysis. Ann Surg. 1992;216(2):172-83.

102. Liu C, Du Z, Lou C, Wu C, Yuan Q, Wang J, et al. Enteral nutrition is superior to total parenteral nutrition for pancreatic cancer patients who underwent pancreaticoduodenectomy. Asia Pac J Clin Nutr. 2011;20(2):154-60.
103. Mazaki T, Ebisawa K. Enteral versus parenteral nutrition after gastrointestinal surgery: a systematic review and meta-analysis of randomized controlled trials in the English literature. J Gastrointest Surg. 2008;12(4):739-55.

104. Yan X, Zhou FX, Lan T, Xu H, Yang XX, Xie CH, et al. Optimal postoperative nutrition support for patients with gastrointestinal malignancy: a systematic review and meta-analysis. Clin Nutr. 2017;36(3):710-21. Epub 2016 Jul 2.

105. Gerritsen A, Besselink MG, Cieslak KP, Vriens MR, Steenhagen $E$, van Hillegersberg $R$, et al. Efficacy and complications of nasojejunal, jejunostomy and parenteral feeding after pancreaticoduodenectomy. J Gastrointest Surg. 2012;16(6):1144-51.

106. Weijs TJ, Berkelmans GH, Nieuwenhuijzen GA, Ruurda JP, Hillegersberg RV, Soeters PB, et al. Routes for early enteral nutrition after esophagectomy. A systematic review. Clin Nutr. 2015;34(1):1-6.

107. Zhu X, Wu Y, Qiu Y, Jiang C, Ding Y. Comparative analysis of the efficacy and complications of nasojejunal and jejunostomy on patients undergoing pancreaticoduodenectomy. JPEN J Parenter Enteral Nutr. 2014;38(8):996-1002.

108. Abu-Hilal M, Hemandas AK, McPhail M, Jain G, Panagiotopoulou I, Scibelli T, et al. A comparative analysis of safety and efficacy of different methods of tube placement for enteral feeding following major pancreatic resection. A non-randomized study. JOP. 2010;11(1):8-13.

109. Torres Júnior LG, de Vasconcellos Santos FA, Correia MI. Randomized clinical trial: nasoenteric tube or jejunostomy as a route for nutrition after major upper gastrointestinal operations. World J Surg. 2014;38(9):2241-6.

110. Moro K, Koyama Y, Kosugi SI, Ishikawa T, Ichikawa H, Hanyu T, et al. Low fat-containing elemental formula is effective for postoperative recovery and potentially useful for preventing chyle leak during postoperative early enteral nutrition after esophagectomy. Clin Nutr. 2016;35(6):1423-8.

111. Sodergren $M H$, Jethwa $P$, Kumar $S$, Duncan HD, Johns $T$, Pearce CB. Immunonutrition in patients undergoing major upper gastrointestinal surgery: a prospective double-blind randomised controlled 
study. Scand J Surg. 2010;99(3):153-61.

112. Liu H, Ling $W$, Shen $Z Y$, Jin $X$, Cao H. Clinical application of immune- enhanced enteral nutrition in patients with advanced gastric cancer after total gastrectomy. J Dig Dis. 2012;13(8):401-6.

113. Ryan AM, Reynolds JV, Healy L, Byrne M, Moore J, Brannelly $N$, et al. Enteral nutrition enriched with eicosapentaenoic acid (EPA) preserves lean body mass following esophageal cancer surgery: results of a double-blinded randomized controlled trial. Ann Surg. 2009;249(3):355-63.

114. Marik PE, Zaloga GP. Immunonutrition in high-risk surgical patients: a systematic review and analysis of the literature. JPEN J Parenter Enteral Nutr. 2010;34(4):378-86.

115. Marimuthu K, Varadhan KK, Ljungqvist O, Lobo DN. A meta-analysis of the effect of combinations of immune modulating nutrients on outcome in patients undergoing major open gastrointestinal surgery. Ann Surg. 2012;255(6):1060-8.

116. Aguilar-Nascimento JE, Campos AC, Borges A, Correia MITD, Tavares GM. Terapia nutricional no perioperatório. Projeto Diretrizes. 2011;339-54.

117. McClave SA, Taylor BE, Martindale RG, Warren MM, Johnson DR, Braunschweig C, McCarthy MS, Davanos E, Rice TW, Cresci GA, Gervasio JM, Sacks GS, Roberts PR, Compher C; Society of Critical Care Medicine.; American Society for Parenteral and Enteral Nutrition. Guidelines for the Provision and Assessment of Nutrition Support Therapy in the Adult Critically III Patient: Society of Critical Care Medicine (SCCM) and American Society for Parenteral and Enteral Nutrition (A.S.P.E.N.). JPEN J Parenter Enteral Nutr. 2016;40(2):159- 211.

118. Braga $M$, Ljungqvist $O$, Soeters $P$, Fearon $K$, Weimann A, Bozzetti F; ESPEN. ESPEN Guidelines on Parenteral Nutrition: surgery. Clin Nutr. 2009;28(4):378-86.

119. de Miranda Torrinhas RS, Santana R, Garcia T, CuryBoaventura MF, Sales MM, Curi R, et al. Parenteral fish oil as a pharmacological agent to modulate postoperative immune response: a randomized, doubleblind, and controlled clinical trial in patients with gastrointestinal cancer. Clin Nutr. 2013;32(4):50310.

120. Wei Z, Wang W, Chen J, Yang D, Yan R, Cai Q. A prospective, randomized, controlled study of $\omega-3$ fish oil fat emulsion-based parenteral nutrition for patients following surgical resection of gastric tumors. Nutr J. 2014;13:25.

121. Long $H$, Yang $H$, Lin $Y$, Situ $D$, Liu W. Fish oilsupplemented parenteral nutrition in patients following esophageal cancer surgery: effect on inflammation and immune function. Nutr Cancer. 2013;65(1):71-5.

122. Wu MH, Wang MY, Yang CY, Kuo ML, Lin MT. Randomized clinical trial of new intravenous lipid (SMOFlipid 20\%) versus medium-chain triglycerides/ long- chain triglycerides in adult patients undergoing gastrointestinal surgery. JPEN J Parenter Enteral Nutr. 2014;38(7):800-8.

123. Ziegler TR, May AK, Hebbar G, Easley KA, Griffith DP, Dave N, et al. 3Efficacy and safety of glutaminesupplemented parenteral nutrition in surgical ICU patients: an American multicenter randomized controlled trial. Ann Surg. 2016;263(4):646-55.

124. Hensley BJ, Cooney RN, Hellenthal NJ, Aquina CT, Noyes K, Monson JR, Kelly KN, Fleming FJ; Upstate New York Surgical Quality Initiative Collaborative. Readmissions after colectomy: The Upstate New York Surgical Quality Initiative Experience. Dis Colon Rectum. 2016;59(5):419-25.

125. Wick EC, Shore AD, Hirose K, Ibrahim AM, Gearhart $\mathrm{SL}$, Efron J, et al. Readmission rates and cost following colorectal surgery. Dis Colon Rectum. 2011;54(12):1475-9.

126. Kassin MT, Owen RM, Perez SD, Leeds I, Cox JC, Schnier K, et al. Risk factors for 30-day hospital readmission among general surgery patients. J Am Coll Surg. 2012;215(3):322-30.

127. Mullen MG, LaPar DJ, Daniel SK, Turrentine FE, Hanks JB, Smith PW. Risk factors for 30-day hospital readmission after thyroidectomy and parathyroidectomy in the United States: An analysis of National Surgical Quality Improvement Program outcomes. Surgery. 2014;156(6):1423-30.

128. Adogwa O, Elsamadicy AA, Mehta Al, Cheng J, Bagley CA, Karikari IO. Preoperative nutritional status is an independent predictor of 30-day hospital readmission after elective spine surgery. Spine (Phila Pa 1976). 2016;41(17):1400-4. 
129. Giles KH, Kubrak C, Baracos VE, Olson K, Mazurak VC. Recommended European Society of Parenteral and Enteral Nutrition protein and energy intakes and weight loss in patients with head and neck cancer. Head Neck. 2016;38(8):1248-57.

130. Crickmer M, Dunne CP, O'Regan A, Coffey JC, Dunne SS. Benefits of post- operative oral protein supplementation in gastrointestinal surgery patients: A systematic review of clinical trials. World J Gastrointest Surg. 2016;8(7):521-32.

131. Sriram K, Sulo S, VanDerBosch G, Partridge J, Feldstein J, Hegazi RA, Summerfelt WT. A comprehensive nutrition-focused quality improvement program reduces 30-day readmissions and length of stay in hospitalized patients. JPEN J Parenter Enteral Nutr. 2017;41(3):384-391. Epub 2016 Dec 6.

132. Beck AM, Holst M, Rasmussen HH. Oral nutritional support of older (65 years+) medical and surgical patients after discharge from hospital: systematic review and meta-analysis of randomized controlled trials. Clin Rehabil. 2013;27(1):19-27.

133. Froghi F, Sanders G, Berrisford R, Wheatley T, Peyser P, Rahamim J, et al. A randomised trial of post-discharge enteral feeding following surgical resection of an upper gastrointestinal malignancy. Clin Nutr. 2016 Nov 5. pii: S0261-5614(16)31314-0. [Epub ahead of print].

134. Bowrey DJ, Baker M, Halliday V, Thomas AL, Pulikottil-Jacob R, Smith $K$, et al. A randomised controlled trial of six weeks of home enteral nutrition versus standard care after oesophagectomy or total gastrectomy for cancer: report on a pilot and feasibility study. Trials. 2015;16:531.

135. Gavazzi C, Colatruglio S, Valoriani F, Mazzaferro V, Sabbatini $A$, Biffi $R$, et al. Impact of home enteral nutrition in malnourished patients with upper gastrointestinal cancer: a multicentre randomised clinical trial. Eur J Cancer. 2016;64:107-12.

Received in: 22/06/2017

Accepted for publication: 20/07/2017

Conflict of interest: none.

Source of funding: none.

\section{Mailing address:}

José Eduardo de Aguilar Nascimento

E-mail: je.nascimentocba@gmail.com / aguilar@terra.com.br 